\title{
Horror Comics and Highbrow Sadism: Televising George Orwell in the 1950s
}

\section{Daniel Lea, Oxford Brookes University}

Exactly how a writer's posthumous reputation is forged and sustained is a curiously creative and singular process. This paper will look at one moment in the afterlife of George Orwell - the B.B.C. TV adaptation of Nineteen Eighty-Four by Nigel Kneale that was broadcast as the Sunday play on $12^{\text {th }}$ December 1954 - both as a micro-moment in the cultural history of Orwell's reputation and as a nexus of social and cultural anxieties in early-1950s Britain. John Rodden has stated of this production that it is 'unusual that one can point to a single moment from which a writer's popularity is "launched" and it is rare that one can chart the public's reaction to a work of art so specifically.1 The production caused an unprecedented controversy with complaints to the B.B.C. and newspapers reaching record levels. The broadcast prompted calls for restraint on TV programming, parliamentary motions and demands for alternative viewing options. It also had a dramatic impact on Orwell's public reputation and book sales that went from respectable to stratospheric bestsellerdom in a matter of days. By examining the history of the controversy, the contexts for its virulence and its effects on Orwell's public image, this essay will attempt to identify in what ways and to what extent Sunday $12^{\text {th }}$ December 1954 played a role in Orwell's posthumous making.

In the early 1950s, British broadcasting was still dominated by sound programming. Though drama had been at the heart of the B.B.C.'s provision since 1936, it was only with the appointment of Michael Barry as the Head of Television Drama in 1952 that original drama began to represent a significant portion of the Corporation's output.2 Barry's Drama Department represented a professional turn with the appointment of a Script Supervisor and a staff of retained writers who, in addition to editing the scripts of others, were tasked with producing original material. Most prominent amongst these was Nigel Kneale, on whom Barry spent the majority of the department's budget in its first year.3 Kneale shared Barry's 
belief that television drama offered more than merely 'illustrated radio' but 'had to rely less on dialogue, more on the "power of the image"..4 Kneale dispensed with "the usual talkie piece set in a couple of rooms in which people said things like "put down that gun, it might be loaded"' and set out instead to produce something 'fast-moving and adventurous'.5 Kneale's breakthrough production - The Quatermass Experiment (1953) - brought him together with Rudolph Cartier, an Austrian producer/director who had been appointed to the B.B.C. by Barry in 1952. Jason Jacobs describes Cartier as 'a major influence on the visual development of British television drama' citing his expansive (and often expensive) vision of the potential of drama as his legacy: where Kneale had been used to scripts that required only three sets, his production work with Cartier on Nineteen Eighty-Four amounted to twenty-two sets and six pre-filmed insert sequences. 6 Cartier's achievement was to break away from the staged quality that live theatrical transmissions radiated, offering instead broader canvases, nuanced visualisations and an intense viewing experience. Equally, Cartier broke with the orthodoxy of intimacy that had governed television drama in its early years. The technical limitations that dictated much production design and directorial scope favoured the close-up as the dominant shooting mode, creating a personal intimacy that became synonymous with television and its distinguishing characteristic over film and theatre. As Cartier commented in 1958:

The T.V. viewer always wants to be as close as possible to the artist, and feels cheated, or disappointed, if the director does not give him the chance to study emotions in close-up.7

Cartier recognised the potential of the persuasive magnetism of the close-up to hook an audience:

The Quatermass Experiment ... [was] more successful on the small T.V. screen ... mainly because of the 'hypnotic' power emanating from the T.V. screen to the viewer, sitting isolated in his darkened room. There is nothing to distract him. 8 
Cartier/Kneale's production of Nineteen Eighty-Four depended upon a similar hypnotic effect achieved using a complex blend of close-up, medium and long shots, pre-filmed inserts and minimal chiaroscuro design.

Suggestions of an adaptation of Nineteen Eighty-Four for TV date from around 1951 and it is clear from materials in the B.B.C. Written Archives that an original transmission date of summer 1953 had been mooted.9 As it turned out, the ambitious and expensive technical and stylistic innovations of Cartier/Kneale's adaptation ensured that the final date for broadcasting would be eighteen months later.10 A significant proportion of the budget was dedicated to securing recognisable lead actors: Peter Cushing (as Winston), Yvonne Mitchell (as Julia) and André Morrell (as O’Brien) were already familiar to TV audiences and some of the most popular and employable actors of the day. By late 1954 the imperative to put the play into production had become pressing as the filming rights for the novel were soon to pass out of the B.B.C.'s hands, a detail unknown to many viewers who complained of the broadcast's proximity to Christmas. Logistically the performances (one on Sunday $12^{\text {th }}$ December followed by a repeat on Thursday $16^{\text {th }}$ ) were complex with a large cast (twentyeight actors), numerous sets, a live orchestra in an adjoining room playing a specially commissioned score and the integration of the pre-filmed inserts with the timing and movements of the cast. Broadcast live, the inserts allowing time for scene, cast and costume changes but still several of the final scenes involve uncommonly and uncomfortably lingering focus on one actor as others are prepared for subsequent shots. As practice dictated, there was no initial intention to telerecord the play and it was only as a response to the controversy after the Sunday performance that the decision was taken to record the Thursday repeat.

Nineteen Eighty-Four was broadcast between $8.35 \mathrm{pm}$ and $10.35 \mathrm{pm}$ on Sunday $12^{\text {th }}$ December 1954. It followed the popular panel show What's My Line? and was not only transmitted at prime time, but also constituted the majority available programming on an 
evening traditionally associated with family viewing. Gerald Scheff in that day's Sunday Express had posted an ominous warning about the tenor of the drama: 'How will the viewing millions react to two hours of unrelieved tension - to a relentless drama which has an ending without hope for humanity?' and B.B.C. announcer, Bronwen Pugh, twice read warnings that the play was 'unsuitable for elderly people or the younger members of the family'.11 Kneale's adaptation of the novel faithfully presented a post-nuclear 1984 of bleak austerity against a backdrop of an authentically war-damaged London. Human interaction is reduced variously to numbed monosyllabism and paranoiac suspicion and the script is spare and atmospheric. Cartier's sparse and understated direction accentuated this tension; it is left to the skill of the actors to convey the horror of submission to the totalitarian Party. One particularly effective scene in which Cartier utilised the power of the close-up, has Cushing realising, in a prefilmed internal monologue, the duplicity of the Party in announcing an increase in the chocolate ration that he knows to have been reduced. Cushing's skills as a classically trained actor are showcased as his facial expressions reveal his disbelief, disgust and finally wariness at the prospect of condemning himself through 'facecrime'.12 The play's 'horrific' elements are confined to the final half-hour and principally consist in the torture scenes and Winston's eventual consignment to Room 101. In the former Cushing is depicted as lying, hollow-eyed and streaked in blood, in a makeshift coffin while a restrained O'Brien administers increasingly powerful electric shocks. The latter is even less explicit with filmed shots of caged rats, a cannibalised gas-mask and a great deal of suggestion standing in for the ultimate torture. Cushing's Winston is barely through the door of Room 101 before he has betrayed Julia. Given that it was the violence primarily of these scenes that generated such appalled controversy, it is interesting to note that as John Rodden says, 'the violence was mild ... by American standards of 1954' but 'the British public in 1954 was quite unprepared for graphic on-stage violence'.13 
Viewing figures for the first performance vary dramatically depending upon which source is consulted: a figure between 4 and 9 million was the estimate in the days after, 14 and subsequent scholarship has not been any more specific, with Sutherland claiming the figure as the largest since the Coronation in 1952 and Rodden asserting that 'the second showing of the play attracted the largest audience in B.B.C.-TV history to that date'.15 More definitive information is contained in Audience Research Reports in the Written Archive which suggest 'that the audience for the origination was $19 \%$ of the adult population of the United Kingdom (equivalent to $63 \%$ of the adult TV public)'. The Report also states that: 'The origination's audience was smaller than any of the previous five Sunday plays, suggesting that some viewers did refrain from viewing, either because they realised from the billing that "1984" would not appeal to them, or because they heeded the preliminary warning of its nature'. 16 Curiously, even though the play's violence was restricted to the final stages, protests began within the first half-hour of transmission leading to the suspicion that elements of the British Left, dissenting at the B.B.C.'s adaptation of Orwell's anti-communist text, were deliberately orchestrating a 'public' backlash.17 Nonetheless, genuinely distressed viewers began telephoning the B.B.C. and newspaper offices at the play's conclusion. Archive files indicate that there were 'many hundreds of telephone calls' to Broadcasting House and the Lime Grove Studios in Shepherd's Bush and newspaper reports the following day predictably record the B.B.C. switchboard being jammed at which many irate viewers began telephoning and telegramming newspaper offices. 18

The nature of the complaints can be gauged by the letters and comments that were published by the press on Monday $13^{\text {th }}$ December. The Daily Mirror's vox pop included reactions such as: 'I have never seen anything so depressing, appalling or horrific'; 'It was the most disgusting play I have seen on TV'; 'It was so awful that I felt like putting a hammer through my TV set' and 'We hear so much about banning horror comics. This was sheer 
horror from start to finish'.19 The News Chronicle reported a Mrs Edna Burgess saying: "“I trembled with fear as I watched. It was not fit for ordinary decent-minded human beings. It was nothing but unoriginal bits of horror put together." Mr Frederick Poate of Woking, was looking in with Canadian friends. "None of us is particularly squeamish, but we found the torture scene where a man was given electric shocks in a coffin was more than we could stand," he said'.20 Meanwhile the Daily Express reported on a particularly tragic reaction to the play: 'A forty-year-old mother of two children collapsed and died while watching the TV horror play 1984, it was disclosed last night. ... A doctor who was called asked at once: 'Was she watching the TV play?'.21

Whilst it would be overstating the case to suggest that the play dominated the newspapers in the succeeding days, much of the press (establishment as well as popular) devoted considerable space to the growing controversy. TV critics were divided about the drama; those in the popular newspapers (such as the Daily Mail, Daily Express, Daily Sketch, and Daily Mirror) tended to reflect the disapprobation of their readerships. In the Daily Mirror, Fergus Cashin complained that:

Nobody was spared the tiresome, confused terror of this depressing and harrowing production. ... There was no moral in this nauseating story which held out no hope for the future that could justify its being shown on TV.22

The Daily Express lamented that 'Once again TV hopelessly miscalculated the tastes of its biggest audience. The B.B.C. warning should have read: "Unsuitable"”, whilst Jonah Barrington in the Daily Sketch opined:

The play has scenes of torture and beastliness such as would never have been passed by any film censor, not even under an Adults Only certificate. The last thirty minutes were like a nightmare journey into hell. ... The play reeks of decadence, disease and corruption. 23

However, alongside the voices declaiming the B.B.C. for broadcasting the play were a significant number who were more positive or considered in their criticism. The Daily Telegraph praised the B.B.C. for the accuracy of its adaptation: 'It is difficult to imagine a 
novel being more faithfully or effectively adapted for television .... The performance was one of the drama department's most polished achievements'; The Times applauded the performance but felt that 'in a dramatic presentation of the book much of the irony is lost', whilst the Manchester Guardian described the production as 'brilliant' but acknowledged that many people would react against its presentation because 'it is a work which must make everyone think'.24 This debate about the play's intellectual demands would become one of the most prevalent tropes of critique in the following days.

In fact, though what grabbed the headlines were the somewhat hysterical rejections of the play's brutal subject-matter, taken as a whole, the press and public response was relatively balanced. Far from the News Chronicle's claim that 'Not one caller praised the play', the B.B.C. received a great many calls, telegrams and letters approving their courage and ambition in showing the play. The Archive shows that of 2,375 letters received (a record for a single programme), 1,586 were protests while 789 were appreciations, many received in response to the critical comments in the news. The B.B.C. call log for the Sunday night also shows that there were a 'good proportion for' the play's broadcast.25 By Tuesday $14^{\text {th }}$ December the News Chronicle was reporting that reaction was split about 50/50 in favour and opposition to the play.26 As the week progressed, these camps became increasingly divided, no more dramatically seen than in an exchange of parliamentary motions and countermotions on $14^{\text {th }}$. This was initiated by five Conservative MPs who tabled a motion condemning 'the tendency, evident in recent British Broadcasting Corporation television programmes, notably on Sunday evenings, to pander to sexual and sadistic tastes'.27 An amendment was tabled by five Labour and one Conservative MP that deplored 'the tendency of honourable members to attack the courage and enterprise of the British Broadcasting Corporation in presenting plays and programmes capable of appreciation by adult minds, on Sunday evenings and other occasions'.28 To this was added another amendment to the 
original that was 'thankful that freedom of the individual still permits viewers to switch off'. Finally a second motion was tabled by six Conservative MPs that applauded 'the sincere attempts of the B.B.C. to bring home to the British people the logical and soul-destroying consequences of the surrender of their freedom'.29

By Wednesday $15^{\text {th }}$ December, attention was turning towards the issue of the programme's repeat on Thursday evening. By this point criticism of the programme was modulating, with some previously antipathetic newspapers (such as the Daily Sketch and the Daily Express) now editorialising in favour.30 The point at issue began to shift from the specifics of the play's violent scenes to a broader discussion about the purpose, value and scope of television. In the face of divided opinion, the B.B.C. determined that the broadcast should be repeated and this decision was, at least morally, ratified by Prince Philip's comment that he and the Queen had watched and enjoyed the programme.31 Nevertheless, the Corporation hastily convened a special edition of the current affairs show, Panorama for the Wednesday evening.32 This debate pitted Michael Barry and Orwell's friend and cultural critic Malcolm Muggeridge, against Jonah Barrington, the Daily Sketch critic and Alderman Herbert Sheppard of Tunbridge Wells. From press coverage it appears that Barry and Muggeridge's defence won the day with the Alderman's argument not developing far beyond an abhorred rejection of the 'sheer, stark, unadulterated horror' of the play. 33 Nineteen Eighty-Four would be repeated at the later time of $9.35 \mathrm{pm}$ with no cuts.

Despite the vocal opposition to the play which by Thursday included Lord MacDonald, chairman of the National Broadcasting Council of Wales, and despite the extra security that was arranged to avoid any attempt to sabotage the production, the repeat appears to have passed off not only without incident but also without a great deal of controversy. 34 The Daily Mail recorded on Friday $17^{\text {th }}$ 
The biggest audience since the Coronation last night saw a repeat of television's most controversial play - George Orwell's "Nineteen Eighty-Four.” It cut cinema attendances and packed public-houses that had TV sets. 35

However B.B.C. Archive statistics suggest a far less impressive viewing figure; only $7 \%$ of the adult population of the UK (equivalent to $23 \%$ of the adult viewing public) in comparison with figures of $19 \%$ and $63 \%$ respectively for the Sunday showing. 23\% was in line with standard figures for Thursday repeats and the Archive report suggests that there was nothing exceptional in the number that turned on. The following morning the Daily Sketch, the Daily Telegraph and the News Chronicle all note a small number of complaints whilst the Daily Mail concludes that opinion was markedly in favour of the play on repeat.

Though the controversy rumbled on into the new year, the play itself swiftly faded from attention. The bigger issues about the nature and purpose of television, the expectations of the audience and the impossibility of meeting the needs of a large and increasingly socially diverse public with one channel ultimately overshadowed the drama. In analysing this public controversy two questions have to be asked about the production: what contexts exist to explain the contentiousness of something so relatively minor, and what impact did the controversy have on Orwell's fame and that of his final novel? In answering the first question it is necessary to address: the role and expectations of the B.B.C. in the early 1950s; conceptions of domesticity and the shape of family life and specifically the debate about 'horror comics' that came to a head in the autumn and winter of 1954. All are, of course, contained within and influenced by the impact of the Cold War and in grouping around Orwell's novel, and its adaptation, this nexus of social and cultural anxieties found a topical focus.

Since the reintroduction of television services in 1946, the B.B.C. had been facing questions about the purpose and scope of television. The exponential spread of television ownership between 1946 and 1955 is outlined by Asa Briggs in his history of British 
broadcasting: in 1955 4,503,766 combined sound and vision licences were obtained in contrast to 1947 when 14,560 licences were issued. 1954 saw a figure of 3,248,852 combined licences issued, a number that dwarfed the 1,600,000 that the B.B.C. had estimated.36 Similarly production of television sets rose astronomically across the period: 6,500 were produced in 1946, compared to $1,771,000$ in 1955.37 This considerable uptake of television as a leisure activity placed great pressure on the B.B.C.; no longer could television programming be comfortably aimed towards an audience of the social and economic elite televisions as desirable commodities were rapidly filtering through the class system. As Briggs comments:

At the end of 1947 it was estimated that $48 \%$ of television sets in use were owned by the better-off $12 \%$ of the population (Class I), $27 \%$ by the $20 \%$ of the population in Class II, and $25 \%$ by the $69 \%$ of the population in Class III. ... This was never quite the whole story. Even at the end of 1947, 22,000 television sets were in Class III homes, more than in Class II homes. Moreover in Class II, given two families of roughly equal economic status but of unequal educational level, those with the lower educational level would be likely to be the ones who bought television sets first. 38

Not only was a television an increasingly familiar object in lower socio-economic homes, but it was also considerably more likely to be switched on: 'When questioned as to whether or not they watched a whole night's programmes from 8.30p.m. to close-down at 10.30p.m., as many as $91 \%$ said yes. Viewing was not selective, therefore, even in the early years of postwar television'.39 Both the wider distribution of sets across the social classes and the relative indiscrimination of watching habits impacted upon the Nineteen Eighty-Four controversy most clearly seen in the debate about the production's perceived intellectualism.

'If the play "Nineteen Eighty Four” is intellectual, thank God I have no brains...' wrote S. Challacombe from Torquay in a letter to the B.B.C. in the week after the broadcast and her/his sentiments were echoed by many others, such as D. Hunt from Leicester who wrote on $15^{\text {th }}$ December: 'For weeks on Sundays we have to watch dismal, immoral and sadistically Highbrow ... plays'.40 The perception that the B.B.C. was pandering to a 
'highbrow' audience in disregard of a significant proportion of the viewership who regarded entertainment as the primary priority of television can be read explicitly or implicitly in many of the programme's reviews, letters and editorials. A number of letters to the press point to the juxtaposition of preceding the play with the family oriented panel show What's My Line? and a reader to the News Chronicle articulated the problem of scheduling for diversity in her comment: 'I wonder if the B.B.C. has any idea what follows in a family group. Do the elders give up their pleasure, or do the younger ones file silently from the room, to go early to bed, or sit and shiver in a cold room elsewhere?' ${ }^{41}$ Repeatedly the intellectual demands on the audience feature as both a positive and negative effect of the drama, with critics such as Robert Knox in Tribune colourfully lambasting the complainers:

In their thousands, the new orthodox - the licence holders - have risen from their nightly swill. They have been insulted. Orwell, thanks to the B.B.C., has pulled the ring in their noses - and it hurts. ... The 1984 affair, however, does emphasise: 1 . The real demand for an alternative television service: true viewers are not obliged to think and feel, they can always switch off, but a Choice of Programme is now one of the inalienable rights of man. 2. The danger of an alternative television service which will wrap its viewers cosily in expensive nonsense, and will never, never, never, disturb or stir, or educate a living soul.42

Knox's is a sentiment echoed, in more moderate language, by the Glasgow Herald, who argued on $16^{\text {th }}$ December: 'The B.B.C. have a statutory duty to do more than provide entertainment. They must inform democracy and give a free play to opinion. It is fair to say that adult citizens who do not know the lesson of "Nineteen Eighty-Four" ought to learn it.' 43 The positions opposed here are a didactic paternalism that argues for the universal benefit of intellectually or ideologically challenging programming by the B.B.C., and a laissez-faire cultural libertarianism that regards television as a vehicle for mass entertainment rather than education. For many commentators in the press (including those in the more popular and populist papers), those viewers who objected to the play were emotionally childlike and intellectually uncurious, viewing TV as the means to a brief and ephemeral end. 
This patriarchalism surfaces repeatedly in the bemused question of why, if so many found the drama offensive, they did not simply switch off. 44 Despite several attempts by newspapers to canvas psychiatrists for the answer to this question, the most straightforward response is provided by Philip Hope-Wallace in The Listener:

And at this point, may I say that a line taken by many others, i.e., 'We are still free. This is not 1984. You could have switched off if you didn't like it', is just as absurd? People don't have television to switch it off. 45

Hope-Wallace's point is, perhaps inadvertently, an interesting one: TV as a consumer luxury (but fast becoming a necessity) represents such a significant financial outlay and social status symbol, that to own one and leave it switched off is nonsensical. TV was rapidly becoming synonymous with family leisure and, as such represented, for some, a threat to the domestic space.

In spite (or perhaps because) of the warning about the play's unsuitability for a younger audience, families seem to have watched the broadcast en masse and intriguingly the subsequent protests often stress the invasion of the domestic space by something disturbing or unwelcome. Robert Cannell in the Daily Mirror plays upon the fireside as an idealised metaphor for family security: 'Nine million people sat by their firesides last night and watched a TV story of misery and pain and wickedness called '1984'” (Cannell, $13^{\text {th }}$ December 1954).46 The familial stronghold is threatened firstly by the division of its members into suitable and unsuitable viewers, and then by the introduction of unsettling images into the home itself. Part of this effect was televisual and emerged as a deliberate ploy by Cartier and Kneale to discomfort the viewer (Cartier's viewer is 'isolated' with 'nothing to distract him', 'unable to find help or comfort by looking around the mass audience in the modern cinema'), but it also reveals an anxiety about the impact of the television on the domestic environment and on the behaviour of those within that environment. 47 The sedentary nature of viewing was clearly a concern for many, such as this respondee to a Mass 
Observation report on television: 'I have no desire whatsoever to have a set ... I think it encourages the growing tendency for passive pastimes.... Since it involves a semi-darkened room and concentration of eyes and ears, it is particularly crippling for any other activity'.48 And it was this exclusive nature of watching that worried many; radio listening had often been accompanied by another activity, television viewing, with its necessary concentration on a small screen, tended to preclude other pastimes. This, Briggs suggests, raised concerns about people's ability to act and he quotes the Director General of the B.B.C., Sir William Haley as saying 'If there is one responsibility that television heightens in broadcasting, it is to ensure that it does not, in the end, make people even more passive than they already are'.49 Time and again the reviews of Nineteen Eighty-Four use terms such as 'soporific',50 'cosily',51 'spoon-fed',52 and 'pap' 53 to describe the effects of television which in no way challenges the intellectual or moral sensibilities; what is presented as being at stake is an audience agency and self-control, qualities that are seen to be being eroded by the TV set. Television is thus portrayed contrarily at this moment as both a soother to an infantilised audience and a malevolent presence in the corner of the room.

Such anxieties about the deleterious effects of viewing are also revealed in the debate over 'horror comics' that raged throughout the autumn and winter of 1954-5. As with the controversy over Nineteen Eighty-Four, the moral panic about these publications was shortlived, but potent. In the early 1950s American crime and horror comics aimed at a juvenile market began to be imported into Britain raising fears not only of delinquent behaviour amongst the young but also of the invasion of an Americanised mass culture. 54 These comics, according to the Manchester Guardian 'specialise in the macabre and the brutal in ways evidently designed to appeal to the aggressive instinct which lurk under the staid surface of more people, probably, than one likes to think'.55 Public concern about these comics, allied to noisy protestations from deputations of teachers and churchmen, stimulated the government 
into action in early December 1954 when it announced that a bill to outlaw the comics would be set before Parliament in the new year. The Harmful Publications Bill was duly presented to the House of Commons in February 1955 and was finally passed on $6^{\text {th }}$ May of that year, by which time it was already redundant as circulation of the comics had been practically curtailed by the refusal of publishers to print and of newsagents to sell the items. As John Sringhall pithily points out: 'The sledge-hammer of parliamentary legislation had been wielded to crack a very small nut indeed'.56

In the row over Nineteen Eighty-Four, the fear of the incipient brutality of the young becomes universalised to represent the potential for brutishness in every individual regardless of age. True, many complained about the production's portrayal of violence as unsuitable for family viewing, but there is little suggestion that younger members of the viewing community would attempt to emulate that violence. Instead the repeated appearance of the horror comic motif in viewers' protests seems to hint at the fear of an innate destructiveness. Many of the initial protests use the still fresh debate as a touchstone for what should and should not be put before an audience: the News Chronicle reports that callers to the B.B.C. described the play as 'worse than horror comics',57 the Daily Mirror records one viewer as saying: 'We hear so much about banning horror comics. This was sheer horror from start to finish' 58 and of the many letters to the B.B.C. one notes: 'we have all come to the conclusion that the persons responsible for putting on the play are sadists and readers of Horror comics'.59 Peter Cushing, the star of the play was asked his opinion of the comparison by the Daily Express to which he responded: 'In the play, Orwell shows a factory producing horror comics to debase the minds of the people. If his play is a horror comic, then it is a horror comic to expose what horror comics can do.' 60 MP Christopher Hollis waded into the debate on $18^{\text {th }}$ December, rejecting the claim that Orwell's novel was akin to a horror comic but warning: 
... what you cannot argue and remain sane is that Orwell in 1984 or anywhere else makes sadism attractive and encourages people to cruelty, as it is alleged that the comics do. ... Orwell's argument ... is that, if the public does not face the facts about what sort of people only too often hold power in the modern world, they are likely to find themselves under the dominion of such persons before they know where they are. 61

What is at stake here is not primarily the future mindset of the 1954 youth, but the anxiety that violence and manipulation are intrinsic to the human condition and that Orwell's 'prophecy' predicts not just a repeat of the horrors of the 1930s and 40s, but an exacerbation of them. In the context of the Cold War's polarisation of ideological affiliation, Cartier/Kneale's adaptation suggests a bleak, perhaps unavoidable future.

Although Lez Cooke describes the production as 'a major landmark in the history of British television drama',62 it faded from attention very quickly. Though there are a number of press engagements early in 1955, it was quickly overshadowed by the introduction of commercial television on $22^{\text {nd }}$ September 1955. The legislation bringing the Independent Television Association into being had been passed in July 1954, and, as John Sutherland notes: 'The Nineteen Eighty-Four controversy articulated the case for diversity, heterogeneity and audience choice ... . It was at the very least evident that the B.B.C., with its one channel, could no longer please all the British tele-viewing people. Nor could television any longer remain ignored, or be relegated to the status of visual radio. It was now proven to be a medium of unprecedented impact'.63 For many commentators at the time, the furore clarified the absolute necessity for the breaking of the B.B.C.'s monopoly and the introduction of multi-channel television services. The Daily Telegraph, for instance, lamented the lack of choice:

The trouble is that TV has no alternative programme. Though the B.B.C. hope to have theirs going in 1957, no date has been fixed. Commercial TV's first station is expected to start next October. But it may not be ready then. Meanwhile, viewers who do not like what they see must either endure it or switch off. 64 
The eventual stratification of programming into generalist (B.B.C.1), arts (B.B.C.2) and entertainment (I.T.V.) ensured that a repeat of the Nineteen Eighty-Four protest could not happen, making its cultural impact even more compelling. The play was revived on $28^{\text {th }}$ November 1965, with a new cast and some amendments to Kneale's script, as part of B.B.C.2's 'Theatre 625 - The World of George Orwell'. There were no protests and Mary Crozier, reviewing the play for the Guardian, thought this due to the greater level of violence deemed acceptable by 1965.65 The last word on this performance should perhaps be left to Maurice Richardson who, in the Observer complained that the torture scenes were laboured and 'the rats underacted'.66 The recording of Cartier/Kneale's original script was shown in July 1977 as part of Festival 77 to celebrate the Queen's Silver Jubilee, in April 1984 at the National Film Theatre and in July 1994 as part of a Rudolph Cartier retrospective.67 Not without a certain irony the play is now available on YouTube. 68

By far the greatest legacy of the production has been the impact it had on Orwell's reputation. On his death in January 1950, Orwell's reputation as a novelist was at its highest point and, as John Rodden has argued, this estimation was sustained throughout the early 1950s. The popularity of both Animal Farm and Nineteen Eighty-Four on both sides of the Atlantic in particular appeared to have cemented Orwell in a position of eminence in British letters. In terms of copies of Nineteen Eighty-Four sold by the end of 1954, Frederic Warburg records that by the fifth printing of the hardback in 1951, 49,917 copies had been purchased in the UK69, while the first American edition had sold 49,100 in hardback by June 1950, 190,000 in the Book-of-the-Month Club reissue of the first edition by March 1952 and 750,000 in the Signet paperback edition by January 1952.70 Warburg notes that the 1954 Penguin paperback edition had sold 804,300 copies by 197271 though I have been unable to locate exact sales of this edition pre-12 December. Despite these impressive figures, it is clear that sales peaked early with the 1950 Secker and Warburg second edition and its 1951 reissue 
print runs amounting to no more than 8,975.72 Exact sale figures up to December 1954 are difficult to come by, but John Sutherland claims that: 'In the autumn the sales of the Secker sixth edition had slowed to around 150 a month - about enough to warrant keeping the book in print, but nothing very wonderful'. 73 Orwell's readership, though loyal, was by the time of the performance diminishing in new members.

The immediate impact of the TV production was a huge boost in the novel's sales. The Bookseller records on $25^{\text {th }}$ December that although initially demand did not appear to have been stimulated, by the end of the week orders for 1,000 copies of the Secker edition and 18,000 copies of the Penguin edition had been taken. 74 Undoubtedly the serialisation of the novel in Daily Express (from Tuesday $14^{\text {th }}$ ) had boosted that demand but in an aside which perhaps reveals something of the public status of the text, the Bookseller comments on the luck of Secker and Warburg as 'until now nobody at all has considered this acknowledged work of genius worth serialising'.75 Penguin reissued the novel twice in 1955, then again in 1956, 1958 and 1959 suggesting significant numbers of new readers, and in 1973 Warburg calculated that he was still averaging sales on 2,000 copies of the hardback a year. Who all these new readers were is to some extent a matter for conjecture, but we can gain a significant insight into these new markets from the Bookseller's comment that 'until the Daily Express reproduced the book ... the non-bookbuying public had perhaps not realised that Nineteen Eighty-Four was, in fact, a book as well as a TV programme'.76

This assessment suggests two conclusions about the Nineteen Eighty-Four row. Firstly, it indicates why disapprobation was so strident after the first performance: clearly for many, and not just those new to the television constituency, Orwell's vision of a totalitarian future was an unprecedented and unwarranted injection of pessimism for which they were unprepared by prior knowledge of the novel, or Orwell's reputation. What the revulsion shows is not simply a rejection of the play's violence but a more complex collision of high 
and low culture. Television's increasing prevalence amongst the lower socio-economic groups provides us with an intriguing vox pop on Orwell's most famous work (albeit adapted) and on the purpose and limitations of television. Secondly the huge initial demand for copies of Nineteen Eighty-Four in the wake of the performance and the consistently high demand in the years after imply that Orwell's new readers were drawn, in some measure at least, from these socio-economic groups, the very groups to whom his writing appeals but heretofore without being particularly appealing. If this is the moment when Orwell's last novel is 'boosted into the supersellerdom which it has enjoyed ever since and will apparently enjoy for evermore' 77 then it was in part projected there by a device that for many provides little more than pappish 'prolefeed'. In addition it stimulated an intellectual engagement with a literary text amongst a wide and presumably educationally diverse audience that had been so derided for its lack of curiosity by the more elitist cultural critics. The snobbish dismissal of the viewers' reaction to the play begins to appear like a cultural protectionism designed to retain Orwell amongst a critical coterie of the educated fellow traveller and to question the socially democratic aspirations of television services.

The Cartier/Kneale production of Nineteen Eighty-Four has largely faded from the cultural historical record; its impact seems to have been explosive but its effect only temporary. It has been absorbed into the broader industry of Orwelliana that likes to regard its subject as a force of nature, his prescience irrefutable and his omniscience uncanny, but what the controversy shows is a moment of dramatic intervention remoulding and repackaging Orwell for a new and media-literate audience. With its built-in sell-by date, Nineteen EightyFour was always going to ascend to some form of afterlife, but it is doubtful that without Cartier/Kneale Orwell's name would be so widely recognisable. As the Socialist Leader editorialised on Christmas Day 1954:

'The book made no more than a ripple on the waters of public opinion when it was published. ... 1984 might ... have disappeared from the public scene had it not been for 
the televised version of it broadcast on Sunday $12^{\text {th }}$ December. On that night Orwell's name became known to millions of people.' 78

\section{Daniel Lea}

Oxford Brookes University

\footnotetext{
1 John Rodden, The Politics of Literary Reputation: The Making and Claiming of 'St. George' Orwell (Oxford, 1989), p. 274.

2 On early television drama, see Asa Briggs, Sound and Vision: The History of Broadcasting in the United Kingdom Volume 4, (Oxford, 1979) and The BBC: The First Fifty Years, (Oxford, 1985); George W. Brandt (ed.), British Television Drama, (Cambridge, 1981); Lez Cooke, British Television Drama, (London, 2003) and Jason Jacobs, The Intimate Screen: Early British Television Drama, (Oxford, 2000).

3 Briggs, Sound and Vision, p. 689.

4 Jacobs quoted in Cooke, British Television Drama, p. 18.

5 Julian Petley, 'The Manxman: The Career of Nigel Kneale', Monthly Film Bulletin, 56:662 (1989), p. 91.

6 Jacobs, The Intimate Screen, pp. 130-1.

7 Rudolph Cartier, 'A Foot in Both Camps', Films and Filming, 4:12 (1958), p. 10.

8 Ibid.

9 The novel was adapted for British radio in 1950 and dramatised for American television by NBC in 1953.

10 The production was to be the most expensive TV drama to date with a final budget totalling $£ 3,250$. See

B.B.C. Written Archive, Reading (hereafter B.B.C. W.A.), T5/362/1-2.

11 Gerald Scheff, 'Big Brother will Be Watching', Sunday Express, 12 December 1954 (B.B.C. W.A., 14A); Robert Cannell, 'Horror of '1984' angers TViewers', Daily Express, 13 December 1954, (B.B.C. W.A., 14A). 12 Cooke, British Television Drama and Jacobs, The Intimate Screen provide excellent case studies of the technical minutiae of the performance.

13 Rodden, Politics, p. 275.

14 James Thomas states that the programme was beamed into 4 million homes('He Will Debate on TV Why he Wants '1984' banned', News Chronicle, 15 December 1954, p. 3), whilst Robert Cannell in the Daily Express suggests the more ambitious 9 million (Cannell, 'Horror of "1984"”).

15 John Sutherland, 'The Drama Caused by the Camera in Room 101', Times Higher Education Supplement, 30

December 1983, p. 8.; Rodden, (Politics, p. 275).

16 B.B.C. W.A., R9/7/12, Audience Research Reports, Television (VR 54/627) Sept-Dec 1954.

17 James Thomas, 'BBC Will Repeat All of '1984', News Chronicle, 14 December 1954, p. 3; Rumours about the orchestration of the protest appear in David Sylvester, 'Orwell on the Screen', Encounter, 4:3 (1955), p. 35. 18 B.B.C. W.A., R41/176/7, P.C.S. Reports on Programme Correspondence File 5, 1949-1954; 'Protest Storm on TV Horror', News Chronicle, 13 December 1954, p. 1.

19 'Viewers Protest at TV 'Horror' Play', Daily Mirror, 13 December, 1954 (B.B.C. W.A., 14A).

20 'Protest Storm', News Chronicle, 13 December 1954, p. 1.

21 '1984: Wife Dies as She Watches', Daily Express, 14 December, 1954, quoted in Rodden, Politics of Literary Reputation, p. 275.

22 Fergus Cashin, 'Tiresome, confused terror ...', Daily Mirror, 13 December 1954, (B.B.C. W.A., 14A).

23 Cannell, 'Horror of "1984"'; Jonah Barrington, no title, Daily Sketch 13 December 1954, (B.B.C. W.A., 14A).

24 'Orwell Novel Adapted', The Daily Telegraph, 13 December 1954, (B.B.C. W.A., 14A); 'Nineteen Eighty-

Four', The Times, 13 December 1954, p. 11; 'Orwell's "Nineteen Eighty-Four"', Manchester Guardian, 13

December 1954, p. 5.

25 B.B.C. W.A.,R41/176/7, P.C.S. Reports on Programme Correspondence File 5, 1949-1954.
} 
26 Thomas, 'B.B.C. Will Repeat All of '1984', 14 December 1954, p. 3.

27 'Controversy over "1984”", The Times, 15 December, 1954, p. 5.

28 Ibid.

29 Ibid.

30 'Candidus' repudiated fellow Daily Sketch journalist Jonah Barrington for his attack on the play and eulogised

'The B.B.C. achieved heights of brilliance in presentation that television has never known before.' (Candidus, no title, Daily Sketch, 14 December 1954, [B.B.C. W.A., 14A]). The Daily Express began serialising Orwell's novel from Tuesday 14 December.

31 See Myles and Petley, 'Rudolph Cartier', p. 128.

32 Both Sutherland, 'Drama Caused by the Camera'and Rodden, Politics claim that this programme was aired on Monday 13, but as is clear from newspaper coverage, it was arranged for Wednesday 15 (Thomas, 'He Will Debate', p. 3; “"Horror" Play - Or a Warning?, Manchester Guardian, 16 December 1954, p. 14).

33 '“Horror" Play?', p.14; See also Reginald Pound, 'Admiration', Listener, 52:1347, 23 December 1954, p. 1126.

34 'B.B.C. Chief May Vet Sunday Plays', News Chronicle, 16 December 1954, p.5.

35 'TV Repeat of "1984" hits Cinemas', (B.B.C. W.A., 14A).

36 Briggs, Sound and Vision, pp. 240-1.

37 Ibid., p. 242.

38 Ibid., pp. 250-1.

39 Ibid., p. 255.

40 B.B.C. W.A., T5/362/2.

41 Mary M. Clibbom, 'TV is No.1 Family Problem', News Chronicle, 17 December 1954, p. 4.

42 Robert Knox, '1984 and All That', Tribune 17 December 1954, (B.B.C. W.A., 14A).

43 'Nineteen Eighty-Four', Glasgow Herald, 16 December 1954, (B.B.C. W.A., 14A).

${ }_{44}$ Critics who ask why the set wasn't switched off include: 'London Day by Night', The Daily Telegraph, 14 ${ }^{\text {th }}$

December 1954, (B.B.C. W.A., 14A); Knox, '1984 and All That'(B.B.C. W.A., 14A); Thomas, 'B.B.C. Will

Repeat', p. 3.

45 Philip Hope-Wallace, ‘Thirty Years On', Listener, 52:1347, 23 December 1954, pp. 1126-1127.

46 Cannell, "Horror of "1984"”.

${ }_{47}$ Cartier, 'A Foot in Both Camps', p. 10.

48 Briggs, Sound and Vision, p. 260.

49 Ibid., p. 261.

${ }_{50}$ Christopher Hollis, '1984 and Its Critics', Time and Tide, 35:51, 18 December 1954, p. 1711.

51 Knox, '1984 and All That'(B.B.C. W.A., 14A).

52 B.B.C. W.A., T5/362/2, Letter sent to Rudolph Cartier by David Climie, Alec Grahame and Peter Myers from London, dated 13 December 1954.

53 Hope-Wallace, 'Thirty Years On', p. 1126.

54 On the 'Horror Comic' furore see John Sringhall, 'Horror Comics: The Nasties of the 1950s', History Today, 44:7 (1994), pp. 10-13.

55 'Horror Comics', Manchester Guardian, 30 October 1954, p. 4.

56 Sringhall, 'Horror Comics', p. 13.

57 'Protest Storm', News Chronicle, p. 1

58 'Viewers Protest at TV 'Horror' Play', Daily Mirror, 13 December 1954, (B.B.C. W.A., 14A).

59 B.B.C. W.A., T5/362/2, letter to B.B.C. from D. Hunt.

${ }_{60}$ Peter Cushing, 'And the Stars Speak', Daily Express, 14 December 1954, (B.B.C. W.A., 14A).

${ }_{61}$ Hollis, '1984 and its Critics', p. 1711.

${ }_{62}$ Cooke, British Television Drama, p. 31.

${ }_{63}$ Sutherland, 'Drama Caused by the Camera', p. 8.

64 'London Day by Night', The Daily Telegraph, 14 December 1954, (B.B.C. W.A., 14A).

65 Mary Crozier, 'Nineteen Eighty-Four on B.B.C.2', Guardian, 29 November 1965, p. 7.

66 Maurice Richardson, 'Celebrities in Close-Up', Observer, 5 December 1965, p. 25.

67 The play's performance history is detailed at http://www.625.org.uk/1984/sb181984.htm and http://www.themausoleum-club.org.uk

$68 \mathrm{http}: / /$ www.youtube.com/watch?v=hATC_2I1wZE

${ }_{69}$ Frederic Warburg, All Authors Are Equal: The Publishing Life of Frederic Warburg 1936-1971,(London, 1973), pp. 114-15.

70 Gillian Fenwick, George Orwell: A Bibliography, (New Castle, Delaware, 1998), pp. 131-35.

71 Warburg, All Authors Are Equal, p. 115.

72 Fenwick, George Orwell, p. 136. 
73 Sutherland, 'Drama Caused by the Camera', p. 8.

74 'Nineteen Eighty-Four, Bookseller, 2557, 25 December 1954, p. 1948.

75 'Behind the Lines', Bookseller, 2556, 18 December 1954, p. 1935.

76 'Moderate (but growing) demand for most-talked-of book, Bookseller, 2556, 18 December 1954, p. 1922.

77 Sutherland, 'Drama Caused by the Camera', p. 8.

78 'A Childish Outburst', Socialist Leader, 46:52, 25 December 1954, p. 4. 